\title{
Treatment-Resistant Depression Entering Remission Following a Seizure during the Course of Repetitive Transcranial Magnetic Stimulation
}

\author{
Ju-Wan Kim, Kyung-Yeol Bae, Sung-Wan Kim, Hee-Ju Kang, \\ II-Seon Shin, Jin-Sang Yoon, and Jae-Min Kim ${ }^{凶}$ \\ Department of Psychiatry, Chonnam National University Medical School, Gwangju, Republic of Korea
}

Major depressive disorder is often resistant to antidepressant treatment. Repetitive transcranial magnetic stimulation (rTMS) has been used in treatment-resistant depression (TRD). Known adverse events of rTMS include transient headache, local pain, syncope, seizure induction, and hypomania induction. This report outlines a patient with TRD who unexpectedly improved following a seizure during the course of rTMS, which has never been reported.

Psychiatry Investig 2016;13(4):468-471

Key Words Treatment resistant depression, Transcranial magnetic stimulation, Adverse event, Seizure, Remission.

\section{INTRODUCTION}

Depression is a common mental disorder with an annual prevalence of $6.6-16.2 \%$; the lifetime prevalence is approximately $40 \% .{ }^{1}$ Depression is associated with high rates of morbidity and mortality, and psychosocial impairment. ${ }^{2,3}$ When assessing depression treatment outcomes, remission is typically defined in a practical sense as low or absent symptoms, ${ }^{4}$ usually based on assessment scales such as the Hamilton Rating Scale for Depression (HAM-D) ${ }^{5}$ or Montgomery-Asberg Depression Rating Scale (MADRS). ${ }^{6}$ Treatment-resistant depression (TRD) is defined as a lack of remission after at least two adequate trials of treatment with different classes of antidepressants. ${ }^{7,8} \mathrm{TRD}$ is relatively common in clinical practice, with $50-60 \%$ of patients not achieving remission following 8-12 weeks of antidepressant treatment. ${ }^{9}$

To manage TRD, several pharmacotherapeutic approaches can be used, including the addition of another agent or a switch

Received: September 20, 2015 Revised: October 27, 2015

Accepted: October 27, 2015 Available online: March 23, 2016

$\triangle$ Correspondence: Jae-Min Kim, MD, PhD

Department of Psychiatry, Chonnam National University Medical School, 160 Baekseo-ro, Dong-gu, Gwangju 61469, Republic of Korea

Tel: +82-62-220-6143, Fax: +82-62-225-2351, E-mail: jmkim@chonnam.ac.kr

(c) This is an Open Access article distributed under the terms of the Creative Commons Attribution Non-Commercial License (http://creativecommons.org/licenses/by$\mathrm{nc} / 3.0$ ) which permits unrestricted non-commercial use, distribution, and reproduction in any medium, provided the original work is properly cited. to another antidepressant. ${ }^{10,11}$ Several recent studies have confirmed the efficacy of transcranial magnetic stimulation (TMS) in TRD. ${ }^{12,13}$ TMS uses nerve depolarization principles such as a general electrical stimulation method in which the magnetic field formed is transformed into an electric field of the appropriate intensity and time. ${ }^{14}$ Repetitive TMS (rTMS) can change the excitement level of the cerebral cortex in a short time period; the changing excitement level is affected by several factors, such as the number, level, frequency, and total number of repeated magnetic stimulations. Of these, the frequency of stimulation is crucial. ${ }^{15}$ Low frequency $(<1 \mathrm{~Hz})$ suppresses the excitement level of the cerebral cortex, while high frequency $(>5 \mathrm{~Hz})$ increases it. ${ }^{16}$

The safety of TMS has been reported in recent meta-analyses. ${ }^{17,18}$ Known complications include hypomania induction, syncope, transient headache, local pain, hearing changes, and burns from the electrodes. Seizure induction has also been reported, with an estimated prevalence of seizures induced by high-frequency rTMS of less than $1 \% .{ }^{19}$ Because electroconvulsive therapy is effective at treating depression ${ }^{20,21}$ and electroconvulsive seizures themselves might counteract depression, ${ }^{22,23}$ a seizure induced by rTMS may have beneficial effects in the treatment of depression. However, there is no report on improvement in a case of depression following a seizure event after rTMS. Here, we present a patient with TRD who improved following a seizure during rTMS treatment. 


\section{CASE}

A 51-year-old woman had suffered from major depressive disorder that had waxed and waned for the last 13 years, with five depressive episodes and three hospitalizations. She had no previous manic or hypomanic episode. She had no personal or family histories of seizure. Her assessment scale scores and medications used for treatment are summarized in Table 1. Four months before her latest hospitalization, her depressive symptoms were exacerbated, and she did not respond adequately despite outpatient treatment that included full doses of two different classes of antidepressants (mirtazapine and venlafaxine) for 2 months, augmented with an atypical antipsychotic (olanzapine). She attempted suicide and was hospitalized. At the time of hospitalization, her scores on the Beck Depression Inventory (BDI) ${ }^{24}$ and HAM-D were 37 and 30, respectively, suggesting severe depression pathologies.

In the hospital, her drugs were adjusted and cognitive behavior therapy was given. However, there was less than $25 \%$ improvement based on the depression assessment scales after 2 weeks of treatment. Since the patient had taken full courses of antidepressants of more than two types and different classes over 10 weeks, we diagnosed her condition as TRD according to various TRD guidelines, including the Committee for Proprietary Medicinal Products guidelines and Massachusetts General Hospital Staging Method. ${ }^{9,10}$ We decided to administer rTMS based on the TRD treatment guidelines. ${ }^{25}$

The treatment protocol was as follows: at $120 \%$ of the motor threshold and a pulse frequency of 10 pulses per second, we administered 80 stimulation cycles of 4 seconds on (active stimulation) and 26 seconds off (no stimulation), resulting in 3,200 pulses per treatment session. After the 11th rTMS, she showed slight improvement, albeit not meaningful clinically. The next day, just before the 12th TMS session, her left lip suddenly quivered for 30 seconds and she drooled. The medical team asked her to spit out a candy she was eating. However, she did not follow these directions, and drooled with a blank facial expression. Subsequently, she could not recall this event. We assessed her condition as an absence seizure, a serious adverse event of rTMS, and decided to stop rTMS treatment. We performed sleep EGG immediately and found dysmorphic theta to delta range slow waves in both cerebral hemispheres with frontal dominancy. Unexpectedly, the next day, the patient's psychopathology changed dramatically. Her mood and cognitive symptoms seemed to improve abruptly and she said that she felt much better and could enjoy watching television. Based on the BDI, HAM-D, and MADRS, her depression had improved to remission status. We believe that her depression improved very rapidly after the seizure. The patient showed no other adverse events related to the seizure, such as cognitive dysfunction, nausea, vomiting, or headache. We repeated her sleep EGG one week later and found theta to delta range slow waves in both cerebral hemispheres with frontal dominance, but no abnormal epileptiform discharges. She was discharged in stable condition on the 38th day of admission. Three months after discharge, she remains in stable condition with no further seizures on a stable medication dose.

Table 1. Assessment scale scores and medication doses during the treatment period

\begin{tabular}{|c|c|c|c|c|c|c|c|c|c|c|c|c|}
\hline \multirow{2}{*}{ Dates } & \multicolumn{3}{|c|}{ Before admission } & \multicolumn{8}{|c|}{ Hospitalization period } & \multirow{2}{*}{$\begin{array}{c}\begin{array}{c}\text { After } \\
\text { discharge }\end{array} \\
+3 \\
\text { months }\end{array}$} \\
\hline & $\begin{array}{c}-4 \\
\text { months }\end{array}$ & $\begin{array}{c}-1 \\
\text { month }\end{array}$ & $\begin{array}{c}-2 \\
\text { weeks }\end{array}$ & 0 & $\begin{array}{c}+7 \\
\text { days }\end{array}$ & $\begin{array}{l}+14 \\
\text { days }\end{array}$ & $\begin{array}{l}+17 \\
\text { days }\end{array}$ & $\begin{array}{l}+24 \\
\text { days }\end{array}$ & $\begin{array}{l}+29 \\
\text { days }\end{array}$ & $\begin{array}{l}+31 \\
\text { days }\end{array}$ & $\begin{array}{l}+38 \\
\text { days }\end{array}$ & \\
\hline Events & & & & dmission & & & $\begin{array}{c}\text { rTMS } \\
\text { start }\end{array}$ & & $\begin{array}{c}\text { Seizure } \\
\text { rTMS hold }\end{array}$ & & Discharge & \\
\hline \multicolumn{13}{|l|}{ Scale scores } \\
\hline HAM-D & 24 & 26 & 24 & 30 & 26 & 24 & 21 & 21 & & 7 & 5 & 8 \\
\hline MADRS & & & & & 30 & 30 & 29 & 21 & & 8 & 5 & 9 \\
\hline $\mathrm{BDI}$ & 28 & 36 & 35 & 37 & 34 & 35 & & 24 & & 3 & 9 & 11 \\
\hline MMSE & & & & & & & & & 30 & & & \\
\hline \multicolumn{13}{|l|}{ Medication, mg } \\
\hline Mirtazapine & & 30 & 60 & 60 & 30 & 30 & 30 & 30 & 30 & 30 & 30 & 30 \\
\hline Venlafaxine & 150 & 150 & 225 & 225 & 150 & 150 & 150 & 150 & 150 & 150 & 150 & 150 \\
\hline Olanzapine & & 5 & 5 & 5 & 10 & 7.5 & 5 & 5 & & 2.5 & 2.5 & \\
\hline Alprazolam & 0.125 & 0.8 & 0.8 & 0.8 & 0.85 & 1 & 1 & 0.8 & 0.5 & 0.5 & 0.5 & 0.5 \\
\hline
\end{tabular}

HAM-D: Hamilton Rating Scale for Depression, MADRS: Montgomery-Asberg Depression Rating Scale, BDI: Beck Depression Inventory, MMSE: Mini-Mental State Exam, rTMS: repetitive transcranial magnetic stimulation 


\section{DISCUSSION}

A TMS-induced seizure is a rare, but significant, adverse event in patients with no history of seizures, even when rTMS is used within the suggested guidelines. Therefore, TMS needs to be supervised by a clinician in a facility capable of responding to a potential seizure quickly. ${ }^{26,27}$ In this report, we present a case of TRD that unexpectedly improved following a seizure during the course of rTMS. As far as we aware, this has never been reported.

There are several possible explanations for the patient's rapid improvement. First, the psychotropic medications may have had a cumulative effect. The patient received full doses of two different antidepressants for 10 weeks after her exacerbation in this episode, but there was minimal symptom change during this period. Therefore, it is difficult to believe that her sudden improvement was due to the effects of these medications. Second, the cumulative effects of rTMS could also be considered. Perhaps the 11 rTMS sessions performed led to her improvement. However, there had been no change in the scores on the depression rating scales up to the 11th rTMS session. Third, the seizure, which was a side effect of rTMS, could have had an effect similar to electroconvulsive therapy (ECT). ECT or magnetic seizure therapy (MST) improves depression by triggering intentional seizures based on convulsive stimulation. ${ }^{20,21,28}$ ECT affects depression by changing neurotransmitter receptors and second-messenger systems. ECT sessions downregulate postsynaptic $\beta$-adrenergic receptors and alter the muscarinic, cholinergic, and dopaminergic neuron systems. ${ }^{29}$ Remission usually takes 6-12 ECT sessions, but remission of depression has followed ultrabrief pulse ECT. ${ }^{30}$ Several studies have reported the molecular effects of electroconvulsive seizures (ECS); ECS increases the expression of genes in the brain-derived neurotrophic factor/ neural receptor protein-tyrosine kinase/mitogen-activated protein kinase pathway, arachidonic acid pathway, and genes for vascular endothelial growth factor, thyrotropin-releasing hormone, neuropeptide $\mathrm{Y}$, and regulators of neuronal sprouting and neurogenesis. ${ }^{22,31,32}$ Single and repeat ECS can cause expression of these genes. ${ }^{23}$ However, the seizures in ECS are generalized tonic-clonic seizures and not the absence seizure that occurred in our case.

This case was reported in order to share our unusual observations of depression improvement after a seizure that occurred as a side effect of rTMS treatment. Psychotropic drugs, especially antidepressants and antipsychotics, may reduce the seizure threshold and provoke seizures. ${ }^{33}$ Among psychotropics, bupropion immediate-release (IR) and clozapine have relatively high seizurogenic potential. ${ }^{34}$ We postulate that seizures caused by the use of psychotropics during rTMS treat- ment might be used to treat resistant depression. However, this may also lead to the development of an epileptic disorder, as in ECT. This possibility needs more empirical research and verification.

\section{Acknowledgments}

This study was supported by a grant from the Korean Health Technology R\&D Project, Ministry of Health \& Welfare, Republic of Korea (HI12C0003).

\section{REFERENCES}

1. Kessler RC, Berglund P, Demler O, Jin R, Koretz D, Merikangas KR, et al. The epidemiology of major depressive disorder: results from the $\mathrm{Na}-$ tional Comorbidity Survey Replication (NCS-R). JAMA 2003;289:30953105.

2. Cassano P, Fava M. Depression and public health: an overview. J Psychosom Res 2002;53:849-857.

3. Riolo SA, Nguyen TA, Greden JF, King CA. Prevalence of depression by race/ethnicity: findings from the national health and nutrition examination survey III. Am J Public Health 2005;95:998-1000.

4. Frank E, Prien RF, Jarrett RB, Keller MB, Kupfer DJ, Lavori PW, et al. Conceptualization and rationale for consensus definitions of terms in major depressive disorder. Remission, recovery, relapse, and recurrence. Arch Gen Psychiatry 1991;48:851-855.

5. Hamilton M. A rating scale for depression. J Neurol Neurosurg Psychiatry 1960;23:56-62.

6. Montgomery SA, Asberg M. A new depression scale designed to be sensitive to change. Br J Psychiatry 1979;134:382-389.

7. Berlim MT, Turecki G. Definition, assessment, and staging of treatment-resistant refractory major depression: a review of current concepts and methods. Can J Psychiatry 2007;52:46-54.

8. Rush AJ, Trivedi MH, Wisniewski SR, Stewart JW, Nierenberg AA, Thase ME, et al. Bupropion-SR, sertraline, or venlafaxine-XR after failure of SSRIs for depression. N Engl J Med 2006;354:1231-1242.

9. Fava M. Diagnosis and definition of treatment-resistant depression. Biol Psychiatry 2003;53:649-659.

10. Souery D, Papakostas GI, Trivedi GH. Treatment-resistant depression. J Clin Psychiatry 2006;67(Suppl 6):16-22.

11. Fava M. New approaches to the treatment of refractory depression. J Clin Psychiatry 2000;61(Suppl 1):26-32.

12. Lefaucheur JP, Andre-Obadia N, Antal A, Ayache SS, Baeken C, Benninger DH, et al. Evidence-based guidelines on the therapeutic use of repetitive transcranial magnetic stimulation (rTMS). Clin Neurophysiol 2014;125:2150-2206.

13. George MS, Post RM. Daily left prefrontal repetitive transcranial magnetic stimulation for acute treatment of medication-resistant depression. Am J Psychiatry 2011;168:356-364.

14. Ridding MC, Rothwell JC. Is there a future for therapeutic use of transcranial magnetic stimulation? Nat Rev Neurosci 2007;8:559-567.

15. Williams JA, Imamura M, Fregni F. Updates on the use of non-invasive brain stimulation in physical and rehabilitation medicine. J Rehabil Med 2009;41:305-311.

16. Siebner HR, Rothwell J. Transcranial magnetic stimulation: new insights into representational cortical plasticity. Exp Brain Res 2003;148: 1-16.

17. Loo CK, McFarquhar TF, Mitchell PB. A review of the safety of repetitive transcranial magnetic stimulation as a clinical treatment for depression. Int J Neuropsychopharmacol 2008;11:131-147.

18. Janicak PG, O’Reardon JP, Sampson SM, Husain MM, Lisanby SH, Rado JT, et al. Transcranial magnetic stimulation in the treatment of major depressive disorder: a comprehensive summary of safety experience from acute exposure, extended exposure, and during reintroduc- 
tion treatment. J Clin Psychiatry 2008;69:222-232.

19. Rossi S, Hallett M, Rossini PM, Pascual-Leone A; Safety of TMS consensus Group. Safety, ethical considerations, and application guidelines for the use of transcranial magnetic stimulation in clinical practice and research. Clin Neurophysiol 2009;120:2008-2039.

20. Rasmussen K. The practice of electroconvulsive therapy: recommendations for treatment, training, and privileging. J ECT 2002;18:58-59.

21. Husain MM, Rush AJ, Fink M, Knapp R, Petrides G, Rummans T, et al. Speed of response and remission in major depressive disorder with acute electroconvulsive therapy (ECT): a consortium for research in ECT (CORE) Report. J Clin Psychiatry 2004;65:485-491.

22. Altar CA, Whitehead RE, Chen R, Wortwein G, Madsen TM. Effects of electroconvulsive seizure and antidepressants on BDNF protein in rat brain. Biol Psychiatry 2003;54:703-709.

23. Altar CA, Laeng P, Jurata LW, Brockman JA, Lemire A, Bullard J, et al. electroconvulsive seizures regulate gene expression of distinct neurotrophic signaling pathways. J Neurosci 2004;24:2667-2677.

24. Beck AT, Ware CH, Mendelson M, Mock J, Erbaugh J. An inventory for measuring depression. Arch Gen Psychiatry 1961;4:561-571.

25. Transcranial magnetic stimulation for severe depression. Available at: http://www.nice.org.uk/guidance/ipg242. Accessed July, 2015.

26. Schlaepfer TE, George MS, Mayberg H; WFSBP Task Force on Brain Stimulation. WFSBP guidelines on brain stimulation treatments in psychiatry. World J Biol Psychiatry 2010;11:2-18.

27. Belmaker B, Fitzgerald P, George MS, Lisanby SH, Pascual-Leone A, Schlaepfer TE, et al. Managing the risks of repetitive transcranial stimulation. CNS Spectr 2003;8:489.

28. Kayser S, Bewernick BH, Matusch A, Hurlemann R, Soehle M, Schlaepfer TE. Magnetic seizure therapy in treatment-resistant depression: clinical, neuropsychological and metabolic effects. Psychol Med 2015; 45:1073-1092.

29. Sadock BJ, Sadock VA, Ruiz P. Kaplan \& Sadock's Synopsis of Psychiatry, 11th Edition. Philadelphia: Wolters Kluwer, 2014, p.1065-1081.

30. Rasmussen KG, Johnson EK, Kung S, Farrow SL, Brown SK, Govrik $\mathrm{MN}$, et al. An open-label, pilot study of daily right unilateral ultrabrief pulse electroconvulsive therapy. J ECT 2016;32:33-37.

31. Wahlestedt C, Blendy JA, Kellar KJ, Jeilig M, Widerlöv E, Ekman R. Electroconvulsive shocks increase the concentration of neocortical and hippocampal neuropeptide $\mathrm{Y}(\mathrm{NPY})$-like immunoreactivity in the rat. Brain Res 1990;507:65-68. 